\title{
Labor History at the Social Science History Association
}

\author{
Lisa McGirr \\ Columbia University
}

Labor history was a prominent theme at the 1993 meeting of the Social Science History Association. Most striking was the attention to questions of gender. If the papers at the conference are any sign, the field has made substantial progress toward answering Alice-Kessler Harris's 1984 call at the DeKalb labor history conference to bring gender into the center of labor history research. Other central themes at the meeting were the impact of ethnicity on working-class formation, class consciousness, and working-class culture.

One of the most interesting papers was presented by Lisa Sullivan at the panel on "Masculinity, Militance, and Maintenance: Representations of Labor in the Twentieth Century." In her paper "'Real' Work and the Maintenance of Identity; The Symbolic Significance of Traditional Labor in the Recent Economic History of Newfoundland," Sullivan found a fundamental gap between policy makers' understanding of the meaning of work and that of the Newfoundland workers themselves. This gap has doomed all economic revitalization efforts in Newfoundland to failure. She convincingly demonstrated the centrality of the values of independence, autonomy, and of individual control over the work process within Newfoundland workers' culture. Policy makers' recognition of these values, she suggested, is vital to the success of any future programs. At the same panel, C. Joseph Cugini explored the gendered nature of the IWW's notions of militance in his paper "Redrawing Gendered Notions of Militance: The I.W.W. and the Lawrence Bread and Roses Strike." The IWW's counterhegemonic, antibourgeois culture, he argued, was profoundly masculinist. Cugini convincingly showed how masculine notions of militance were transformed during the Lawrence strike due to the importance of women in the struggle. Nancy Palmer, in "Confronting a Masculine Labor Movement: The Place of Solidarity and Militance in the Lives of Women Electrical Union Organizers," analyzed how wartime loyalty discourse operated to shape and limit female union organizers' opportunities within the labor movement.

In a panel on "Gender and Class in Comparative Perspective: The United States, England and France," participants discussed the intersection of gender and class in three different settings. In her paper "Mutuality and Marginality: Gender Relations and the Nineteenth Century English Working Classes," Carole Morgan argued that notions of marginality are insufficient to explain gender relations among workers in the nineteenthcentury British cotton industry. While gender relations were made and 
remade around work and the structure of the labor market, women's paid and domestic labor, she asserted, were not viewed in opposition to each other but as part of a mutual struggle with working-class men to sustain their families and communities. Carole Turbin's innovative paper, "The Social History of the White Collar," argued that the development of the detachable collar in the United States during the late nineteenth and early twentieth centuries represented a new configuration of class and gender. Laura Frader, in her paper "Gender, Parties and Organized Labor in Interwar France," found that working-class women used the politicization of women's bodies during the 1920 s to demand rights as social citizens. But the struggle for social citizenship on the basis of women's sexual embodiment, Frader suggested, was a double-edged sword: It served the interests of the state in very conservative ways while simultaneously enabling women to demand and reclaim rights.

In a similar vein, Kathleen Canning, in a session on class consciousness and identity formation, argued that unionized female textile workers in Germany articulated a politics of the body in order to contest the hegemonic politics of class during the 1920s. Looking at the feminization of union politics as women entered the social-democratic textile union in large numbers, she suggested that women rewrote the meaning of class in the mid-1920s. Through inserting a female body into political debate, she said, women successfully contested and recast the dominant meanings of body politics and of class. Attention to discourse was a thread which wove through many papers at the meeting, but nowhere more centrally than in Mark Steinberg's "The Labor of the Country is the Wealth of the Country; Class Identity, Consciousness and the Role of Discourse in the Making of the English Working Class." Steinberg examined how the language of the Spitalfield weavers of London was part of the process of constructing class identity and consciousness. The weavers of Spitalfield, he asserted, successfully subverted the legitimacy of bourgeois meanings and simultaneously fashioned shared interests as well as an oppositional consciousness within the dominant discourse.

A panel on "Working Class Internationalism" focused on the relationship between ethnicity and class. In his paper on the "Interplay of Class and Ethnicity in Polish-American Radicalism," Thad Radzilowski examined the large Polish-American community of Hamtramck during the 1930 s. He convincingly argued that community ties facilitated class-based activity and contributed to the militance and success of the auto workers' sit-down strikes. Ethnic ties, he suggested, were also strengthened through new class identities. Stan Nadel looked at German immigrants in New York in the nineteenth century in his paper "Anthropological Models to Incorporate both Class and Ethnicity into a Single Framework of Identity." He found that, like class, ethnicity was made, not found. To many German immigrants who identified themselves as Rhinelanders, Platt-Deutsch, or Brandenburgers, Germany was meaningless in its generality. Through in- 
ternal as well as external pressures, a common German ethnicity was built out of these diverse identities.

Another paper that focused on German immigrants in nineteenthcentury Chicago took a somewhat different tack. In his paper "Work Traditions, Ideology, and Culture: Organizing German Immigrant Workers in 19th Century America," Hartmut Keil asserted that the process of organization among German-American workers was intimately related to prior experiences in Germany. Prior experiences shaped radical visions which helped establish lasting trade unions. These workers' outlooks, he suggested, strongly influenced the U.S. labor movement and fed directly into the structures and goals of the AFL. Similarly, Fraser Ottanelli's paper on "Ethnicity and Working Class Internationalization: Italian-American Radicals in the Interwar Period" drew a correlation between prior experiences in the home country and activism in the United States. Ottanelli found that prior labor and political experience in Italy corresponded with antifascist work in the United States.

In a panel on "Labor Historians and the Decline of Organized Labor," participants discussed the future prospects of a labor history faced with a shrinking labor movement. Nancy Gabin and Eric Arnesen, focusing on women and African Americans, respectively, expressed optimism about the future of labor history. Arnesen urged historians to examine historically specific racisms and how unions have contributed both to the advance and lack of advance for African Americans. Future research, he noted, should not only look at workers within unions but at the variety of the African-American experience. Nancy Gabin was cautiously optimistic that the growth of unionization in areas where women are a majority may reverse the traditional view that unions do not appeal to women. Howard Kimeldorf and Michael Merrill's reinterpretations of American workingclass history turned conventional wisdom on its head. Kimeldorf, in "Unions and the Making of the American Working Class," argued that American workers and their unions have been characterized by neosyndicalism: workers were militant and combative, expressing an industrial rather than a political radicalism. In a similar revisionist vein, Michael Merrill, in his paper "Our Great Evasion: Samual Gompers, the AFL, and Workers' Power in the United States," argued that workers in the United States have had more power, within an international perspective, and have in some ways been in power, and most workers, he asserted, have known this to be the case. Commentator Marianne Debouzy critiqued the unabashed revisionism of these two papers. She also addressed the critical question of the panel, a question faced by all labor historians: Can labor history expand in a meaningful way with a shrinking labor movement? She was pessimistic. But if the conference is a sign, labor history is indeed flourishing, though perhaps the continued compartmentalization, the lack of synthesis, and the linguistic turn evident at the meeting reflect the future of a labor history deprived of political impetus. 